\title{
Some photosynthetic and growth responses of Annona glabra L. seedlings to soil flooding
}

\author{
Marcelo S. Mielke ${ }^{1,2}$, Elyabe M. Matos ${ }^{1}$, Virginia B. Couto ${ }^{1}$, Alex-Alan F. de Almeida ${ }^{1}$, Fábio P. Gomes ${ }^{1}$ and \\ Pedro Antonio Oliveira Mangabeira ${ }^{1}$
}

Received: April 27, 2004. Accepted: June 07, 2005

\begin{abstract}
RESUMO - (Algumas respostas fotossintéticas e do crescimento de plântulas de Annona glabra L. ao alagamento do solo). Um experimento foi conduzido com o objetivo de analisar os efeitos do alagamento e da posição das folhas na produtividade primária líquida e no balanço de carbono em plântulas de Annona glabra L. (Annonaceae), uma espécie altamente tolerante ao alagamento e nativa na América tropical. Todas as plântulas sobreviveram ao período de alagamento de 56 dias sem apresentarem sintomas de estresse. $\mathrm{O}$ alagamento induziu incrementos significativos $(P<0,01)$ na biomassa de raízes, caules e planta inteira, e na razão raízes/parte aérea. Medições das trocas gasosas foliares foram conduzidas aos quatro, 11, 18 e 56 dias após o alagamento, na primeira (L1), quarta (L4) e sétima (L7) folha completamente expandida a partir do ápice em cada plântula. Os valores médios da condutância estomática ao vapor de água $\left(g_{s}\right)$ e da taxa fotossintética líquida $(A)$ nas plântulas controle foram $0,26 \mathrm{~mol} \mathrm{~m}^{-2} \mathrm{~s}^{-1} \mathrm{e} 8,8 \mu \mathrm{mol} \mathrm{m}^{-2} \mathrm{~s}^{-1}$, respectivamente. Reduções significativas $(P<0,05)$ em $A$ foram observadas entre L1 e L7 nas plântulas controle em todos os três dias de medições. As reduções em $A$ com o aumento da idade foliar também ocorreram nas plantas alagadas, apenas nos dias 4 e 18. O alagamento induziu alterações significativas em $g s(P<0,05)$, alcançando $65 \%$ em relação ao controle no dia 4 e $152 \%$ em relação ao controle no dia 56 . Com base nos resultados obtidos foi possível concluir que as elevadas taxas de sobrevivência e de crescimento de plântulas de $A$. glabra estão diretamente relacionadas com a capacidade de manter elevados valores de condutância estomática e de taxa fotossintética líquida em condições de alagamento do solo.
\end{abstract}

Palavras-chave: Annonaceae, condutância estomática, floresta atlântica, taxa fotossintética líquida, tolerância ao alagamento

ASTRACT - (Some photosynthetic and growth responses of Annona glabra L. seedlings to soil flooding). An experiment was conducted with the aim to analyze the effects of soil flooding and leaf position on net primary productivity and whole plant carbon balance of Annona glabra L. (Annonaceae) seedlings, a highly flood-tolerant tree, native to the tropical Americas. All seedlings survived a period of 56 days of flooding without symptoms of stress. Flooding induced significant increments in root, stem and whole-plant biomass $(P<0.01)$, and in the root:shoot mass ratio $(P<0.05)$. Measurements of leaf gas exchange were conducted at days four, 11, 18 and 56 after flooding, on the first (L1), fourth (L4) and seventh (L7) fully expanded leaves from the apex of each seedling. The mean values of stomatal conductance to water vapour $\left(g_{s}\right)$ and net photosynthetic rate $(A)$ in the control seedlings were around $0.26 \mathrm{~mol} \mathrm{~m}^{-2} \mathrm{~s}^{-1}$ and $8.8 \mu \mathrm{mol} \mathrm{m} \mathrm{m}^{-2} \mathrm{~s}^{-1}$, respectively. Significant reductions $(P<0.05)$ in $A$ were observed from L1 to L7 in controls at all four days of measurements. Reductions in $A$ with increasing leaf age also ocurred for flooded plants, but only at days four and 18. Flooding induced significant changes in $g s(P<0.05)$, reaching $65 \%$ of controls at day four but $152 \%$ of controls at day 56 . Based on the results we conclude that the high survival and growth rates of A. glabra seedlings are directly related to the capacity to mantain a high stomatal conductance and net photosynthetic rate under soil flooding.

Key words: Annonaceae, stomatal conductance, Brazilian Atlantic rainforest, net photosynthetic rate, flood tolerance

\section{Introduction}

Soil flooding is a common environmental stress in gallery forests, wetlands and some regions with high rainfall and poor soil drainage (Pezeshki 1994; Kozlowski 1997). In woody plants soil flooding induces a series of alterations in physiology, such as changes in photosynthesis and in the absorption of macronutrients, death of roots or suppression of their metabolism, and alterations in hormonal balance (Kozlowski 1997). Changes in net photosynthetic rates are generally attributed to diffusional limitation and metabolic inhibition of photosynthesis. The limitation of $\mathrm{CO}_{2}$ diffusion into leaves is due to the closing of stomata (Gravatt \& Kirby 1998; Sena Gomes \& Kozlowski 1988; Núñez-Elisea et al. 1999) and

\footnotetext{
1 Universidade Estadual de Santa Cruz, Departamento de Ciências Biológicas, Rodovia Ilhéus-Itabuna, km 16, CEP 45650-000, Ilhéus, BA, Brasil

2 Correponding Author: msmielke@uesc.br
} 
seedlings of some flood-tolerant trees have the potential to keep the stomata open during waterlogging (Sena Gomes \& Kozlowski 1980; Pezeshki et al. 1996; Gravatt \& Kirby 1998). The re-opening of stomata in flood-tolerant trees was generally related to anatomical and morphological adaptations, such as the appearance of hypertrophic lenticels or adventitious roots. Metabolic inhibition of photosynthesis under soil flooding conditions, on the other hand, can be related to decreases in the activity of Ribulose 1,5 bisphosphate carboxilase/oxigenase (Rubisco), alterations in the sink-source relationships and decreases in nutrient absorption and leaf chlorophyll content (Kozlowski 1997; Pezeshki 2001).

The net photosynthetic rates of leaves after full expansion generally shows a linear decline with age (Kikuzawa 1991). In some tree species changes in the photosynthetic capacity with leaf age are related to changes in resource allocation, mainly by the decline in leaf nitrogen content and deactivation of enzymes of the Calvin cycle (Kitajima et al. 1997). Several studies have investigated the effects of leaf age and leaf position on the net photosynthetic rates in trees (Zotz \& Winter 1994; Ackerly \& Bazzaz 1995; Brooks et al. 1996; Kitajima et al. 1997; Miyaji et al. 1997) and some of these investigations have focused on the interactive effects of environmental factors, i.e. shading, and leaf age on net photosynthesis (Ackerly \& Bazzaz 1995; Brooks et al. 1996; Miyaji et al. 1997). Besides, leaf senescence under soil flooding conditions is a characteristic symptom of stress in flood-sensitive tree species (Kozlowski 1997) and some investigations have demonstrated that flooding can extend leaf longevity in flood-tolerant species (Terazawa \& Kikuzawa 1994).

Annona glabra L. (Annonaceae) is a floodtolerant tree (Zotz et al. 1997; Núñez-Elisea et al. 1999) native in the tropical Americas (Schaffer 1998). It is a small tree that reaches between 4 to $7 \mathrm{~m}$ tall and, in permanently flooded habitats, presents a high relationship between root to shoot biomass (Zotz et al. 1997). In southern Bahian atlantic rainforest, Brazil, this species is naturally found along the gallery forests that replace mangrove vegetation in the rivers flowing into the Atlantic Ocean and in flood-prone habitats of sandbank ecosystems. Due to its high flood tolerance and wide geographical distribution, the species can be recommended for use in gallery forest restoration programs. Moreover, A. glabra has been used as rootstock for several fruit trees of the genus Annona, in order to improve the commercial plantations in areas subjected to periodic flooding (Núñez-Elisea et al.
1999). Studies on the effects of flooding on water relations and anatomy of A. glabra were conducted by Zotz et al. (1997) and Núñez-Elisea et al. (1999). These studies indicated that the high flood tolerance of A. glabra is related to a) the development of hypertrophied lenticels on stems and submerged roots and b) the production of a massive root system, that compensates for the high resistance to water flow in the roots under soil flooding conditions. Notwithstanding, the relationships between leaf gas exchange and biomass partitioning of A. glabra seedlings under soil flooding conditions were not studied. In this way, the present experiment was conducted with the aim to test the hypothesis that flooding affect photosynthetic characteristics of leaves with different ages in Annona glabra L. seedlings and that these alterations are related to the high capacity to survive and grow under permanent soil flooding conditions.

\section{Material and methods}

Seeds were collected from wild trees growing at Ponta do Ramo locality, Ilhéus, Bahia, Brazil, in April 2002 and were placed to germinate in the nursery of Escola Técnica Agropecuária da CEPLAC (EMARC), Uruçuca, Bahia. The seedlings grew in polyethylene bags containing $2.5 \mathrm{~kg}$ of soil under partially shaded environment until September 2002, when they were transferred to the shade house at the campus of the Universidade Estadual de Santa Cruz (UESC), Ilhéus, Bahia, Brazil. The experiment was conducted under a partially shaded structure that transmitted $75 \%$ of full sunlight. On December $2^{\text {nd }}$, 2002, 88 seedlings were selected, among which eight seedlings were used for the growth evaluations at time zero and the others were divided in two groups of 40 seedlings, one exposed to flooding and the other to normal water conditions (control). At the beginning of the experiment seedlings had approximately $400 \mathrm{~mm}$ in height. Flooding was applied by placing the polyethylene bags in $150 \times 150 \times 300 \mathrm{~mm}$ plastic buckets, with two seedlings per bucket. The buckets were then filled with water to 10 to $20 \mathrm{~mm}$ above soil level. Normal water conditions were maintained by irrigating the nonflooded plants daily.

Growth parameters were evaluated at the beginning and end of the experiment (i.e. 56 days after flooding). The parameters evaluated were: collar diameter, stem length, number of leaves, total leaf area per seedling and dry mass of leaves, stems and roots. The leaf areas were estimated using an automatic Leaf 
Area Meter LI-3000 (Li-Cor Inc., Nebraska, USA). Dry mass was obtained by weighing the plant material after drying at $75^{\circ} \mathrm{C}$ until a constant mass was reached.

Leaf gas exchange was measured at days four, 11, 18 and 56 after flooding, always between 08:00 hr and 12:30 hr, using a portable photosynthesis measuring system LI-6400 (Li-Cor Inc., Nebraska, USA). Measurements were taken from three mature and completely expanded leaves of four seedlings per treatment. Because of the monopodial growth pattern, a characteristic of $A$. glabra seedlings, and in order to study the effect of leaf position on leaf gas exchange measurements, we used a modified leaf plastochron index, in which the first (L1), fourth (L4) and seventh (L7) fully expanded leaves from the apex were selected. At the beginning of the experiment, around 16 leaves per seedling were present, from which the first completely expanded leaf per seedling (L1) was the third or fourth leaf from the apex. The same leaves were used in all measurements. Net photosynthetic rate $(A)$, stomatal conductance to water vapor $\left(g_{s}\right)$ and leaf internal $\mathrm{CO}_{2}$ concentrations $(\mathrm{Ci})$ were estimated by the instantaneous values of humidity and $\mathrm{CO}_{2}$ concentrations of air entering and leaving the chamber, determined by the infrared gas analyzer of the portable photosynthesis system. Values of atmospheric $\mathrm{CO}_{2}$ concentration $(\mathrm{Ca})$, air temperature $(\mathrm{Ta})$, external and internal photosynthetic photon flux densities (PFD) were obtained by the sensors of the equipment, while vapor pressure deficit (VPD) was calculated with the values of $T a$ and RH, according to Buck (1981). The ratio of internal and atmospheric $\mathrm{CO}_{2}$ concentrations $(\mathrm{Ci} / \mathrm{Ca})$ was calculated by the quotient between $\mathrm{Ci}$ and $\mathrm{Ca}$. Intrinsic water use efficiency (WUE) was calculated by the quotient between $A$ and $g_{s}$. We also calculated the ratio between stomatal conductance and vapour pressure deficit ( $g s / \mathrm{VPD}$ ), in order to analyze the effects of treatments and leaf age on the response of stomata movement to the evaporative demand of the air surrounding leaves.

During measurements, an artificial light source 6400-02B RedBlue was used, and PFD were adjusted to $1200 \mu \mathrm{mol}$ photons $\mathrm{m}^{-2} \mathrm{~s}^{-1}$, which was above the light saturation point. The mean values of VPD, $T a$, PFD (measured by the external sensor of the chamber) and $\mathrm{Ca}$ during the leaf gas exchange measurements were $1.63 \pm 0.04 \mathrm{kPa}, 32.0 \pm 0.2^{\circ} \mathrm{C}, 460.5 \pm 37.7 \mu \mathrm{mol}$ photons $\mathrm{m}^{-2} \mathrm{~s}^{-1}$, and $381.7 \pm 0.3 \mu \mathrm{mol} \mathrm{mol}^{-1}$, respectively (mean \pm SE, $n=96$ ).

The experiment was conducted in a completely randomized design. For the analysis of leaf gas exchange parameters, the experiment was treated as a $2 \times 3$ factorial, with two levels of water treatment (flood and control) and three leaf ages. Each treatment combination of the factorial designs had four repetitions. Statistical analysis was based on ANOVA followed by Tukey's test. At the end of the experiment, the effects of water regime treatments (flooded and control) on the growth parameters and relative growth rates were compared using a $t$-test, with eight repetitions per treatment.

\section{Results}

All the seedlings survived the period of 56-days of flooding without symptoms of stress, except for a slight chlorosis of the leaves. Hypertrophic lenticels at the base of the stems were also observed and were clearly visible from the first week after flooding.

Significant increases $(P<0.01$, t-test $)$ in root, stem and total plant biomass and in collar diameter were observed in the seedlings of the flooded treatment (Table 1). However, no significant changes were observed for leaf biomass, leaf area, number of leaves and height. On average, only one new leaf per seedling was formed along the 56 days of the experiment. The strong increment in root biomass (152\% of control) also induced significant change $(P<0.05$, t-test $)$ in the root:shoot ratio. Roots, stems and whole-plant growth rates of flooded seedlings were 157,136 and $142 \%$ of controls, indicating that flooding enhanced whole-plant carbon balance.

The mean values of $g_{s}$ were significantly higher $(P<0.05$, Tukey's test) in controls than in flooded

Table 1. Mean $( \pm$ SE, $n=8)$ values of growth parameters of Annona glabra L. seedlings grown under flooded and control conditions for 56 days.

\begin{tabular}{lrc}
\hline Characteristics & Control & Flooded \\
\hline Root biomass $(\mathrm{g})$ & $2.93 \pm 0.19$ & $4.47 \pm 0.37 * *(152)$ \\
Stem biomass $(\mathrm{g})$ & $2.56 \pm 0.17$ & $3.43 \pm 0.25 * *(134)$ \\
Leaves biomass $(\mathrm{g})$ & $1.31 \pm 0.10$ & $1.24 \pm 0.06 \mathrm{~ns}(95)$ \\
Whole plant biomass $(\mathrm{g})$ & $6.82 \pm 0.42$ & $9.15 \pm 0.60 * *(134)$ \\
Leaf area $\left(\mathrm{m}^{2}\right)$ & $2.31 \pm 0.16$ & $2.20 \pm 0.10 \mathrm{~ns}(95)$ \\
Number of leaves & $17.50 \pm 0.76$ & $17.63 \pm 0.96 \mathrm{~ns}(101)$ \\
Collar diameter $(\mathrm{mm})$ & $10.6 \pm 0.40$ & $12.1 \pm 0.40 *(115)$ \\
Height (mm) & $532.0 \pm 11.9$ & $510.3 \pm 16.1 \mathrm{~ns}(96)$ \\
Root:shoot ratio & $0.77 \pm 0.03$ & $0.96 \pm 0.06 *(125)$ \\
\hline
\end{tabular}

For the growth and biomass parameters statistical significance between treatments were given by the t-test, where $* * P<0.01$ and $* P<0.05$. Numbers inside parentheses are the percentage values of flooded plants relative to the controls. 
seedlings at day four, while an opposite response was observed at day 56 (Table 2). In flooded seedlings $g_{s}$ increased from $65 \%$ of controls at day four to $152 \%$ of controls at day 56. The mean values of $g s$ and $A$ observed in the control seedlings were $0.26 \mathrm{~mol} \mathrm{~m}^{-2} \mathrm{~s}^{-1}$ and $8.8 \mu \mathrm{mol} \mathrm{m}^{-2} \mathrm{~s}^{-1}$, respectively. The mean values of $A$ did not differ significantly $(P<0.05$, Tukey's test) between flooded seedlings and controls in any day of measurement, but decreased significantly $(P<0.05$, Tukey's test) from L1 to L7 at all days of measurements.

The $\mathrm{Ci} / \mathrm{Ca}$ ratio varied in a similar way to that observed for gs. Its mean values were around 0.81 in control, but increased from 0.74 at day four to 0.87 at day 56 (approximately $107 \%$ of control) in the flooded plants (Table 3). In spite of no significant differences between different leaf ages, some increments in the $\mathrm{Ci} / \mathrm{Ca}$ ratio were observed from $\mathrm{L} 1$ to $\mathrm{L} 7$, mainly at days four and 56. At day four, the mean value of intrinsic WUE was significantly higher $(P<0.05$, Tukey's test) in control than in flooded seedlings, whereas inverse responses were observed at day 56 . The ratio $g_{s} / \mathrm{VPD}$ showed the same tendency that was observed for $\mathrm{Ci} / \mathrm{Ca}$, indicating that as the time advances a changed in the sensitivity of stomatal conductance to vapour pressure deficit occurs, mainly in the basal leaves of flooded plants, in which the highest values were observed at days 11,18 and $56(0.33,0.27$ and $0.29 \mathrm{~mol} \mathrm{H}_{2} 0 \mathrm{~m}^{-2} \mathrm{~s}^{-2} \mathrm{kPa}^{-1}$, respectively).

\section{Discussion}

Flood-tolerant and intolerant trees show the tendency to close the stomata few days after the soil flooding (Sena Gomes \& Kozlowski 1980; 1988; Pezeshki et al. 1996; Gravatt \& Kirby 1998; Lopez \& Kursar 1999; Núñez-Elisea et al. 1999; Davanso et al. 2002). Decreases in stomatal conductance under flooded conditions are attributed to a decrease in root hydraulic conductivity (Davies \& Flore, 1986; Pezeshki, 2001) or to the production of abscisic acid in the roots or leaves (Zhang \& Zhang, 1994). In most flood-tolerant species the initial decrease in stomatal conductance is followed by recovery (Kozlowski 1997). In the present experiment, $g s$ was reduced to $65 \%$ of control levels with four days of flooding, but reached $116 \%, 115 \%$ and $152 \%$ of controls at days 11,18 and 56, respectively. For a number of floodtolerant trees, the values of $g_{s}$ during flooding rarely returns so closely to the values measured in controls (Sena Gomes \& Kozlowski 1980; Gravatt \& Kirby 1998; Lopez \& Kursar 1999), and it is evident that $A$. glabra is highly adapted to both periodic or permanent flooding.

Table 2. Mean values of stomatal conductance to water vapor $\left(g s, \mathrm{~mol} \mathrm{H}_{2} \mathrm{O} \mathrm{m}^{-2} \mathrm{~s}^{-1}\right)$ and net photosynthetic rates $\left(A, \mu \mathrm{mol} \mathrm{CO}_{2} \mathrm{~m}^{-2} \mathrm{~s}^{-1}\right)$ in the first (L1), fourth (L4) and seventh (L7) fully expanded leaves of Annona glabra L. seedlings grown under soil flooded and control conditions for 56 days.

\begin{tabular}{|c|c|c|c|c|c|c|c|c|c|}
\hline Parameter & $\begin{array}{l}\text { Days of } \\
\text { flooding }\end{array}$ & Treatment & L1 & $\mathrm{L} 4$ & & L7 & & Mean & \\
\hline \multirow[t]{8}{*}{ gs } & \multirow[t]{2}{*}{04} & Control & $0.27 \pm 0.02 \mathrm{aA}$ & $0.26 \pm 0.02$ & $\mathrm{aA}$ & $0.26 \pm 0.02 \mathrm{aA}$ & 0.26 & \pm 0.01 & A \\
\hline & & Flooding & $0.17 \pm 0.02 \mathrm{aB}$ & $0.20 \pm 0.02$ & $\mathrm{aA}$ & $0.16 \pm 0.04 \mathrm{aB}$ & 0.17 & \pm 0.02 & B \\
\hline & \multirow[t]{2}{*}{11} & Control & $0.32 \pm 0.04 \mathrm{a}$ & $0.32 \pm 0.02$ & $\mathrm{a}$ & $0.29 \pm 0.05 \mathrm{a}$ & 0.31 & \pm 0.02 & A \\
\hline & & Flooding & $0.37 \pm 0.05 \mathrm{a}$ & $0.33 \pm 0.03$ & $\mathrm{a}$ & $0.39 \pm 0.02 \mathrm{a}$ & 0.36 & \pm 0.02 & A \\
\hline & \multirow[t]{2}{*}{18} & Control & $0.30 \pm 0.06 \mathrm{aA}$ & $0.27 \pm 0.04$ & $\mathrm{aA}$ & $0.27 \pm 0.04 \mathrm{aA}$ & 0.28 & \pm 0.02 & A \\
\hline & & Flooding & $0.33 \pm 0.02 \mathrm{aA}$ & $0.28 \pm 0.04$ & $\mathrm{aA}$ & $0.34 \pm 0.02 \mathrm{aA}$ & 0.32 & \pm 0.02 & A \\
\hline & \multirow[t]{2}{*}{56} & Control & $0.28 \pm 0.07 \mathrm{aA}$ & $0.23 \pm 0.04$ & $\mathrm{aB}$ & $0.22 \pm 0.04 \mathrm{aB}$ & 0.25 & \pm 0.03 & $\mathrm{~B}$ \\
\hline & & Flooding & $0.36 \pm 0.04 \mathrm{aA}$ & $0.37 \pm 0.03$ & $\mathrm{aA}$ & $0.41 \pm 0.02 \mathrm{aA}$ & 0.38 & \pm 0.02 & A \\
\hline \multirow[t]{8}{*}{$A$} & \multirow[t]{2}{*}{04} & Control & $10.85 \pm 0.80 \mathrm{aA}$ & $9.19 \pm 0.76$ & $\mathrm{abA}$ & $7.77 \pm 0.52$ bA & 9.27 & \pm 0.50 & A \\
\hline & & Flooding & $9.88 \pm 0.71 \mathrm{aA}$ & $8.44 \pm 0.56$ & $\mathrm{abA}$ & $6.55 \pm 0.67 \mathrm{bA}$ & 8.29 & \pm 0.51 & A \\
\hline & \multirow[t]{2}{*}{11} & Control & $10.94 \pm 0.89 \mathrm{a}$ & $9.77 \pm 0.90$ & $\mathrm{ab}$ & $8.11 \pm 0.38 \mathrm{~b}$ & 9.61 & \pm 0.51 & A \\
\hline & & Flooding & $10.48 \pm 0.54 \mathrm{a}$ & $8.94 \pm 0.44$ & $\mathrm{a}$ & $8.34 \pm 0.16 \mathrm{a}$ & 9.25 & \pm 0.33 & $\mathrm{~A}$ \\
\hline & \multirow[t]{2}{*}{18} & Control & $10.51 \pm 0.47 \mathrm{aA}$ & $8.38 \pm 0.59$ & $\mathrm{bA}$ & $7.67 \pm 0.38 \mathrm{bA}$ & 8.85 & \pm 0.42 & A \\
\hline & & Flooding & $10.03 \pm 0.57 \mathrm{aA}$ & $8.13 \pm 0.45$ & $\mathrm{bA}$ & $7.50 \pm 0.38 \mathrm{bA}$ & 8.55 & \pm 0.39 & $\mathrm{~A}$ \\
\hline & \multirow[t]{2}{*}{56} & Control & $10.31 \pm 0.96 \mathrm{aA}$ & $7.77 \pm 0.50$ & $\mathrm{bA}$ & $6.54 \pm 0.32 \mathrm{bA}$ & 8.20 & \pm 0.56 & $\mathrm{~A}$ \\
\hline & & Flooding & $8.99 \pm 0.46 \mathrm{aA}$ & $8.20 \pm 0.52$ & $\mathrm{aA}$ & $8.02 \pm 0.62 \mathrm{aA}$ & 8.41 & \pm 0.29 & $\mathrm{~A}$ \\
\hline
\end{tabular}

Means followed by the same letter are not significantly different by Tukey's test $(P<0.05)$. Capital letters represent comparisons between water treatments and lower case represent comparisons between leaves. 
Table 3. Mean values of the ratio between internal and atmospheric $\mathrm{CO}_{2}$ concentrations $(\mathrm{Ci} / \mathrm{Ca}$ ), intrinsic water use efficiency (WUE, $\mu$ mol $\mathrm{CO}_{2}$ mmol $\mathrm{H}_{2} \mathrm{O}^{-1}$ ) and ratio between $g s$ and vapour pressure deficit ( $g s / \mathrm{VPD}$ ) in the first (L1), fourth (L4) and seventh (L7) fully expanded leaves of Annona glabra L. seedlings grown under soil flooded and control conditions for 56 days.

\begin{tabular}{|c|c|c|c|c|c|c|c|}
\hline Parameter & $\begin{array}{l}\text { Days of } \\
\text { flooding }\end{array}$ & Treatment & L1 & & $\mathrm{L} 4$ & L7 & Mean \\
\hline \multirow[t]{8}{*}{$\mathrm{Ci} / \mathrm{Ca}$} & \multirow[t]{2}{*}{04} & Control & $0.78 \pm 0.02$ & $\mathrm{aA}$ & $0.81 \pm 0.01 \mathrm{aA}$ & $0.83 \pm 0.02 \mathrm{aA}$ & $0.81 \pm 0.01 \mathrm{~A}$ \\
\hline & & Flooding & $0.70 \pm 0.03$ & $\mathrm{aB}$ & $0.77 \pm 0.01 \quad \mathrm{aA}$ & $0.76 \pm 0.03 \mathrm{aB}$ & $0.74 \pm 0.02 \mathrm{~B}$ \\
\hline & \multirow[t]{2}{*}{11} & Control & $0.81 \pm 0.02$ & $\mathrm{a}$ & $0.83 \pm 0.02 \mathrm{a}$ & $0.83 \pm 0.03 a$ & $0.82 \pm 0.01 \mathrm{~A}$ \\
\hline & & Flooding & $0.83 \pm 0.02$ & $\mathrm{a}$ & $0.85 \pm 0.01 \mathrm{a}$ & $0.87 \pm 0.01 \quad \mathrm{a}$ & $0.85 \pm 0.01 \mathrm{~A}$ \\
\hline & \multirow[t]{2}{*}{18} & Control & $0.80 \pm 0.02$ & $\mathrm{aA}$ & $0.83 \pm 0.01 \mathrm{aA}$ & $0.84 \pm 0.01 \quad \mathrm{aA}$ & $0.82 \pm 0.01 \mathrm{~A}$ \\
\hline & & Flooding & $0.83 \pm 0.01$ & $\mathrm{aA}$ & $0.84 \pm 0.01 \mathrm{aA}$ & $0.87 \pm 0.01 \quad \mathrm{aA}$ & $0.85 \pm 0.01 \mathrm{~A}$ \\
\hline & \multirow[t]{2}{*}{56} & Control & $0.78 \pm 0.03$ & $\mathrm{aB}$ & $0.81 \pm 0.03 \mathrm{aB}$ & $0.83 \pm 0.03 \mathrm{aA}$ & $0.81 \pm 0.02 \mathrm{~B}$ \\
\hline & & Flooding & $0.85 \pm 0.01$ & $\mathrm{aA}$ & $0.87 \pm 0.01 \mathrm{aA}$ & $0.88 \pm 0.01 \mathrm{aA}$ & $0.87 \pm 0.01 \mathrm{~A}$ \\
\hline \multirow[t]{8}{*}{ WUE } & \multirow[t]{2}{*}{04} & Control & $41.5 \pm 5.40$ & $\mathrm{aA}$ & $35.3 \pm 2.50 \mathrm{aA}$ & $31.4 \pm 3.70 \mathrm{aB}$ & $36.1 \pm 2.30 \mathrm{~B}$ \\
\hline & & Flooding & $60.0 \pm 6.50$ & $\mathrm{aB}$ & $43.7 \pm 2.40 \quad \mathrm{aA}$ & $47.1 \pm 7.60 \quad \mathrm{aA}$ & $50.3 \pm 3.60 \mathrm{~A}$ \\
\hline & \multirow[t]{2}{*}{11} & Control & $35.1 \pm 3.60$ & $\mathrm{a}$ & $31.0 \pm 4.60 \mathrm{a}$ & $31.5 \pm 7.00 \mathrm{a}$ & $32.5 \pm 2.70 \mathrm{~A}$ \\
\hline & & Flooding & $30.1 \pm 4.30$ & $\mathrm{a}$ & $27.1 \pm 1.30 \mathrm{a}$ & $21.6 \pm 1.20 \mathrm{a}$ & $26.3 \pm 1.70 \mathrm{~A}$ \\
\hline & \multirow[t]{2}{*}{18} & Control & $38.4 \pm 5.30$ & $\mathrm{aA}$ & $31.6 \pm 2.00 \mathrm{aA}$ & $29.7 \pm 2.90 \quad \mathrm{aA}$ & $33.3 \pm 2.10 \mathrm{~A}$ \\
\hline & & Flooding & $30.3 \pm 2.20$ & $\mathrm{aB}$ & $30.3 \pm 3.40 \quad \mathrm{aB}$ & $22.4 \pm 1.70 \mathrm{aB}$ & $27.7 \pm 1.70 \mathrm{~B}$ \\
\hline & \multirow[t]{2}{*}{56} & Control & $40.8 \pm 6.40$ & $\mathrm{aA}$ & $36.6 \pm 5.10 \mathrm{aA}$ & $31.2 \pm 4.90 \mathrm{aA}$ & $36.2 \pm 3.00 \mathrm{~A}$ \\
\hline & & Flooding & $25.4 \pm 1.80$ & $\mathrm{aB}$ & $22.2 \pm 1.60 \mathrm{aB}$ & $19.5 \pm 0.80 \mathrm{aB}$ & $22.4 \pm 1.00 \mathrm{~B}$ \\
\hline \multirow[t]{8}{*}{$g_{s} / \mathrm{VPD}$} & \multirow[t]{2}{*}{04} & Control & $0.18 \pm 0.02$ & $\mathrm{a}$ & $0.17 \pm 0.01 \quad \mathrm{a}$ & $0.16 \pm 0.03 \mathrm{a}$ & $0.17 \pm 0.01 \mathrm{~A}$ \\
\hline & & Flooding & $0.10 \pm 0.01$ & a & $0.12 \pm 0.01 \quad \mathrm{a}$ & $0.09 \pm 0.03 \quad \mathrm{a}$ & $0.10 \pm 0.01 \mathrm{~B}$ \\
\hline & \multirow[t]{2}{*}{11} & Control & $0.26 \pm 0.05$ & $\mathrm{a}$ & $0.26 \pm 0.04 \mathrm{a}$ & $0.23 \pm 0.06 \mathrm{a}$ & $0.25 \pm 0.02 \mathrm{~A}$ \\
\hline & & Flooding & $0.32 \pm 0.05$ & a & $0.28 \pm 0.03 \mathrm{a}$ & $0.33 \pm 0.01 \quad \mathrm{a}$ & $0.31 \pm 0.02 \mathrm{~A}$ \\
\hline & \multirow[t]{2}{*}{18} & Control & $0.27 \pm 0.08$ & $\mathrm{a}$ & $0.22 \pm 0.05 \mathrm{a}$ & $0.21 \pm 0.06 \mathrm{a}$ & $0.23 \pm 0.03 \mathrm{~A}$ \\
\hline & & Flooding & $0.27 \pm 0.01$ & $\mathrm{a}$ & $0.21 \pm 0.04 \mathrm{a}$ & $0.27 \pm 0.03 \quad \mathrm{a}$ & $0.25 \pm 0.02 \mathrm{~A}$ \\
\hline & \multirow[t]{2}{*}{56} & Control & $0.24 \pm 0.06$ & $\mathrm{a}$ & $0.16 \pm 0.04 a$ & $0.16 \pm 0.04 a$ & $0.19 \pm 0.03 \mathrm{~B}$ \\
\hline & & Flooding & $0.25 \pm 0.03$ & $\mathrm{a}$ & $0.26 \pm 0.04 a$ & $0.29 \pm 0.04 \mathrm{a}$ & $0.27 \pm 0.02 \mathrm{~A}$ \\
\hline
\end{tabular}

Means followed by the same letter are not significantly different by Tukey's test $(P<0.05)$. Capital letters represent comparisons between water treatments and lower case represent comparisons between leaves.

The mean values of $A$ observed in this experiment were higher than those reported for other Annona species (Núñez-Elisea et al. 1999). Contrary to $g_{s}, A$ was not significantly affected by soil flooding, indicating that flooding did not affect the photochemical and/or biochemical phases of photosynthesis. The $\mathrm{Ci} / \mathrm{Ca}$ ratios in control and flooded seedlings were very high when compared with other tree species adapted to mesic and xeric habitats (Ehleringer \& Cerling 1995), indicating that $A$. glabra is a non-conservative species in relation to water use and needs the presence of high water availability for its optimum growth and development. Increases in the $\mathrm{Ci} / \mathrm{Ca}$ ratio along the flooding period also demonstrate that flooding enhanced stomatal conductance at a higher degree than net photosynthesis.

Decreases in net photosynthetic rates with leaf age were previously reported for many other tree species (Zotz \& Winter 1994; Kitajima et al. 1997; Miyaji et al. 1997; Hiremath 2000). In the present study we also observed decreases in net photosynthetic rates from younger to older leaves and with time of flooding (Table
2 ), in which the maximum and minimum values of $A$ were observed in L1 at day four $\left(10.85 \mu \mathrm{mol} \mathrm{m}^{-2} \mathrm{~s}^{-1}\right)$

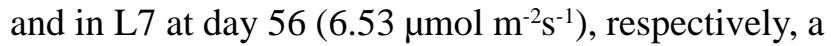
decrease in of $30 \%$. At the end of the experiment, although the mean value of $A$ in L1 was greater in control, it was lowest than flood treatment in L4 and L7, indicating that soil flooding had different effects on $A$ depending of the age of leaves.

Most flood-tolerant neotropical trees, such as Genipa americana (Andrade et al. 1999; Mielke et al. 2003), Calophyllum longifolium, Gustavia superba (Lopez \& Kursar 1999) and Tabebuia avellanedae (Davanso et al. 2002), show decreases in whole plant biomass and root biomass when submitted to soil flooding. The ability to increase root mass under soil flooding conditions, on the other hand, is an uncommon response verified in some floodtolerant trees, such as Nyssa aquatica (McKelvin et al. 1995) and Cytharexyllum myrianthum (Andrade et al. 1999). For example, in C. myrianthum seedlings submmited to flooding for 90 days, Andrade et al. 
(1999) verified significant incremements in roots biomass, height and stem diameter, besides no significant changes were verified in the number of leaves, leaf biomass and stem biomass.

Decreases in the biomass of roots of flooded trees are said to be related to slow metabolic activity under anoxia, since the lack of oxygen blocks mitochondrial electron transport, oxidation of $\mathrm{NADH}+\mathrm{H}^{+}$and ATP synthesis. The impaired mitochondrial respiration enhances glycolysis, which is less efficient in energy production and produces large amounts of pyruvate, which is converted to phytotoxic compounds, such as acetaldehyde, ethanol and lactic acid (Pezeshki 1994; Drew 1997; Gibbs \& Greenway 2003). In anoxic soil conditions, the changes in collar diameter (see Table 1) is associated to hypertrophy of the stem base and sometimes to the formation of aerenchyma. The appearance of hypertrophic lenticels associated with other anatomical and morphological changes, i.e. stem base hypertrophy and aerenchyma, enhance the diffusion of $\mathrm{O}_{2}$ from the atmosphere above the flooded soil and allows normal root respiration and growth (Topa $\&$ McLeod 1986). In a previous study on the effects of flooding on stem anatomy of A. glabra was demonstrated that flooding did not induce aerenchyma formation, although the stem, xylem and fibre cell radius were significatively enhanced (Núñez-Elisea et al. 1999).

The development of hypertrophied lenticels, together with increased mass allocation to roots were the main morphological and physiological adaptations observed in the present and previous studies (NúñezElisea et al. 1999). The greater mass allocated to roots under soil flooding could be a mechanism that counteracts the inefficiency in water absorption and transport by the flooded roots (Davies \& Flore 1986; Pezeshki 2001). The development of a massive root system under soil flooding conditions in A. glabra can be interpreted as a mechanism to compensate for the high resistence to water flow in the roots (Zotz et al. 1997). Increments in the mass allocated to roots and in the root:shoot ratio enhance the capacity to absorb and transport water under soil flooding and partially explain the recovery of stomatal conductance of the flooded seedlings.

The stomata of most terrestrial plants are sensitive to changes in the evaporative demand of the atmosphere (Franks \& Farquhar 1999). Because stomata controls the exchange of $\mathrm{CO}_{2}$ and $\mathrm{H}_{2} \mathrm{O}$ between leaf and atmosphere, this sensitivity results limitation of carbon diffusion inside leaves at high air temperature and low atmospheric humidity, sometimes limiting net primary productivity. The mean values of the ratio $g_{s} / \mathrm{VPD}$ are indicatives that flooding influenced the responses of stomatal conductance to the water demand of the air surrounding the leaves (Table 3). In spite of the greater intrinsic WUE of the control plants at days 18 and 56 (Table 3), we observed that flooding enhanced the net primary productivity and whole-plant biomass (Table 1). So, we suggest that the enhancement in the plant biomass of the flooded seedlings could be explained by the fact that stomata remained open during most part of the day, in contrast to the controls, in which the stomata close at medium to high values of VPD.

Based on the results we confirm the hypothesis that soil flooding affect the leaf gas exchange characteristics of A. glabra seedlings, mainly on the stomatal conductance of basal leaves. The changes in whole plant carbon balance under soil flooding conditions, expressed by the significant changes in the biomass allocated to roots and stems, are characteristics verified in a short number of other floodtolerant tree species (McKelvin et al. 1995; Andrade et al. 1999). In A. glabra, the high survival and growth rates are directly related to the capacity to develop a massive root system and mantain a high stomatal conductance and net photosynthesis under soil flooding.

\section{Acknowledgments}

We thank Arnor Pessoa dos Santos for providing informations about the plant material used in the present study; André M. Amorim and Pedro Fiaschi for taxonomic identification; and Luiz Alberto M. Silva for the assistance in the research facilities. This work was supported by grants of Conselho Nacional de Desenvolvimento Científico e Tecnológico and Universidade Estadual de Santa Cruz.

\section{References}

Ackerly, D.D. \& Bazzaz, F.A. 1995. Leaf dynamics, selfshading and carbon gain in seedlings of a tropical pioneer tree. Oecologia 101: 289-298.

Andrade, A.C.S.; Ramos, F.N.; Souza, A.F.; Loureiro, M.B. \& Bastos, R. 1999. Flooding effects of Cytharexyllum myrianthum Cham. and Genipa americana L.: responses of two neotropical lowland species. Revista Brasileira de Botânica 22: 281-285.

Buck, A.L. 1981. New equations for computing vapor pressure and enhancement factor. Journal of Applied Meteorology 20: 1527-1532. 
Brooks, J.R.; Sprugel, D.G. \& Hinckley, T.M. 1996. The effects of light acclimation during and after foliage expansion on photosynthesis of Abies amabilis foliage within canopy. Oecologia 107: 21-32.

Davanso, V.M.; Souza, L.A.; Medri, M.E.; Pimenta, J.A. \& Bianchini, E. 2002. Photosynthesis, growth and development of Tabebuia avellanedae Lor. ex Griseb. (Bignoniaceae) in flooded soil. Brazilian Archives of Biology and Technology 45: 375-384.

Davies, F.S. \& Flore, J.A. 1986. Flooding, gas exchange and hydraulic conductivity of highbush blueberry. Physiologia Plantarum 67: 545-551.

Drew, M.C. 1997. Oxygen deficiency and root metabolism injury and acclimation under hypoxia and anoxia. Annual Review of Plant Physiology and Molecular Biology 48 : 223-250.

Ehleringer, J.R. \& Cerling, T.E. 1995. Atmospheric $\mathrm{CO}_{2}$ and the ratio of intercellular to ambient $\mathrm{CO}_{2}$ concentrations in plants. Tree Physiology 15: 105-111.

Franks, P.J. \& Farquhar, G.D. 1999. A relationship between humidity response, growth form and photosynthetic operating point in C3 plants. Plant, Cell and Environment 22: 1337-1349.

Gibbs, J. \& Greenway, H. 2003. Mechanisms of anoxia tolerance in plants. I. Growth, survival and anaerobic catabolism. Functional Plant Biology 30: 1-47.

Gravatt, D.A. \& Kirby, C.J. 1998. Patterns of photosynthesis and starch allocation in seedlings of four bottomland hardwood tree species subjected to flooding. Tree Physiology 18: 411-417.

Hiremath, A.J. 2000. Photosynthetic nutrient-use efficiency in three fast-growing tropical trees with differing leaf longevities. Tree Physiology 20: 937-944.

Kikuzawa, K. 1991. A cost-benefit analysis of leaf habit and leaf longevity of trees and their geographical pattern. American Naturalist 138: 1250-1263.

Kitajima, K.; Mulkey, S.S. \& Wright, S.J. 1997. Decline of photosynthetic capacity with leaf age in relation to leaf longevities for five tropical canopy tree species. American Journal of Botany 84: 702-708.

Kozlowski, T.T. 1997. Responses of woody plants to flooding and salinity. Tree Physiology Monograph 1: 1-29.

Lopez, O.R. \& Kursar, T.A. 1999. Flood tolerance of four tropical tree species. Tree Physiology 19: 925-932.

McKelvin, M.R.; Hook, D.D. \& McKee, W.H. 1995. Growth and nutrient use efficiency of water tupelo seedlings in flooded and well-drained soils. Tree Physiology 15: 753-758.
Mielke, M.S.; Almeida, A-A.F.; Gomes, F.P.; Aguilar, M.A.G. \& Mangabeira, P.A.O. 2003. Leaf gas exchange, chlorophyll fluorescence and growth responses of Genipa Americana seedlings to soil flooding. Environmental and Experimental Botany 50: 221-231.

Miyaji, K.; Silva, W.S. \& Alvim, P.T. 1997. Productivity of leaves of a tropical tree, Theobroma cacao, grown under shading, in relation to leaf age and light conditions within the canopy. New Phytologist 137: 463-472.

Núñez-Elisea, R.; Schaffer, B.; Fisher, J.B.; Colls, A.M. \& Crane, J.H. 1999. Influence of flooding on net $\mathrm{CO}_{2}$ assimilation, growth and stem anatomy of Annona species. Annals of Botany 84: 771-780.

Pezeshki, S.R. 1994. Plant response to flooding. Pp. 289-321. In: Wilkinson, R.E. (ed.) Plant-environment interactions. New York, Marcel Dekker.

Pezeshki, S.R. 2001. Wetland plant responses to soil flooding. Environmental and Experimental Botany 46: 299-312.

Pezeshki, S.R.; Pardue, J.H. \& DeLaune, R.D. 1996. Leaf gas exchange and growth of flood-tolerant and floodsensitive tree species under low soil redox conditions. Tree Physiology 16: 453-458.

Schaffer, B. 1998. Flooding responses and water-use efficiency of subtropical and tropical fruit trees in an environmentallysensitive wetland. Annals of Botany 81: 475-481.

Sena Gomes, A.R. \& Kozlowski, T.T. 1980. Growth responses and adaptations of Fraxinus pennsylvanica seedlings to flooding. Plant Physiology 66: 267-271.

Sena Gomes, A.R. \& Koslowski, T.T. 1988. Physiological and growth responses to flooding of seedlings of Hevea brasiliensis. Biotropica 20: 286-293.

Terazawa, K. \& Kikuzawa, K. 1994. Effects of flooding on leaf dynamics and other seedlings responses in floodtolerant Alnus japonica and flood-intolerant Betula platyphylla var. japonica. Tree Physiology 14: 251-261.

Topa, M.A. \& McLeod, K.W. 1986. Aerenchyma and lenticel formation in pine seedlings: a possible avoidance mechanism to anaerobic growth conditions. Physiologia Plantarum 68: 540-550.

Zhang, J. \& Zhang, X. 1994. Can early wilting of old leaves account for much of the ABA accumulation in flooded pea plants? Journal of Experimental Botany 45: 1335-1342.

Zotz, G. \& Winter, K. 1994. Photosynthesis of a tropical canopy tree, Ceiba pentandra, in a lowland forest in Panama. Tree Physiology 14: 1291-1301.

Zotz, G.; Tyree, M.T. \& Patiño, S. 1997. Hydraulic architecture and water relations of a flood-tolerant tropical tree, Annona glabra. Tree Physiology 17: 359-365. 